\title{
Alliance governance choices: Disentangling the effects of uncertainty and alliance experience
}

DOI:

10.1016/j.Irp.2017.07.004

\section{Document Version}

Accepted author manuscript

Link to publication record in Manchester Research Explorer

\section{Citation for published version (APA):}

Niesten, E., \& Jolink, A. (2018). Alliance governance choices: Disentangling the effects of uncertainty and alliance experience. Long Range Planning, 51, 320-333. https://doi.org/10.1016/j.Irp.2017.07.004

\section{Published in:}

Long Range Planning

\section{Citing this paper}

Please note that where the full-text provided on Manchester Research Explorer is the Author Accepted Manuscript or Proof version this may differ from the final Published version. If citing, it is advised that you check and use the publisher's definitive version.

\section{General rights}

Copyright and moral rights for the publications made accessible in the Research Explorer are retained by the authors and/or other copyright owners and it is a condition of accessing publications that users recognise and abide by the legal requirements associated with these rights.

\section{Takedown policy}

If you believe that this document breaches copyright please refer to the University of Manchester's Takedown Procedures [http://man.ac.uk/04Y6Bo] or contact uml.scholarlycommunications@manchester.ac.uk providing relevant details, so we can investigate your claim.

\section{OPEN ACCESS}




\title{
Alliance governance choices: Disentangling the effects of uncertainty and alliance experience
}

\author{
Eva Niesten* \\ University of Manchester
}

\begin{abstract}
Alliance Manchester Business School
University of Manchester

Booth Street East

Manchester M13 9SS

United Kingdom

eva.niesten@manchester.ac.uk
\end{abstract}

Tel: +44 (0) 1613068433

\author{
Albert Jolink \\ Coventry University and Erasmus University Rotterdam
}

*Corresponding author

\author{
Coventry University Business School \\ Coventry University \\ Priory Street \\ Coventry CV1 5FB \\ United Kingdom \\ albert.jolink@ coventry.ac.uk \\ Tel: +44 (0) 2477658634
}

\begin{abstract}
This article analyses the interaction between alliance experience and behavioural uncertainty to improve our understanding of alliance governance. We investigate the extent to which the effect of alliance experience on governance choices is explained by a reduction in "mundane" transaction costs or by a reduction in "opportunistic" transaction costs. Based on more than 12,000 firm experiences with equity and non-equity alliances, we demonstrate a reduction in mundane transaction costs over time by firms reusing the same governance structure in successive alliances. We also find that in high behavioural uncertainty alliances, firms rely on their experience as a substitute for equity governance to reduce opportunistic transaction costs.
\end{abstract}

Keywords: alliance experience; governance; behavioural uncertainty; transaction costs 


\section{INTRODUCTION}

During the formation of a new alliance firms must make a decision on the governance structure of the alliance. Previous research has shown that governance decisions are heavily influenced by the potential for opportunistic behaviour by the firms' alliance partners (Madhok et al., 2015; Sampson, 2004; Williamson, 1996). The study of the hazard of opportunism, also referred to as behavioural uncertainty, has a long tradition in transaction cost economics (TCE). Empirical studies in TCE have shown that firms are much more likely to opt for strong governance safeguards in the form of equity sharing when behavioural uncertainty is high, but firms rely on non-equity alliances when they believe the potential for opportunism is negligible (Hennart, 1988, 1991; Mudambi and Tallman, 2010; Oxley and Sampson, 2004; Sampson, 2004).

Although these studies have contributed important insights on the efficiency of governance structures, they have also been criticized for taking a static perspective on governance (Faems et al., 2008; Reuer et al., 2016). They analyse governance structures as potentially efficient choices at a particular moment in time, but ignore that these choices are influenced by the alliance history of a firm (Gulati, 1995). An emerging research field argues that the study of optimal governance choices should be complemented by a consideration for alliance dynamics (Das and Teng, 2002; Reuer et al., 2016). This article contributes to this emerging research field, and shows that combining the study of alliance dynamics with the study of efficient governance modes leads to a better understanding of firms' governance choices. In this article we study the experience that firms have with different types of governance structures, and in particular their experience with equity and non-equity alliances during a five-year period preceding the new alliance. We propose that governance experience affects governance choices in two different ways; either by reducing "mundane transaction 
costs" over time or by "reducing opportunistic transaction costs" (Baldwin, 2008; Langlois, 2006).

The first effect is derived from studies that argue that governance choices are influenced by the governance structures that firms have experienced in the past (Argyres and Mayer, 2007; Faems et al., 2008). Firms reuse the same governance structures in successive alliances to reduce the costs of establishing and managing new alliances ( $\mathrm{Li}$ et al., 2010). Langlois (2006) and Baldwin (2008) have referred to these costs as "mundane transaction costs". Examples of these costs include the costs of describing, communicating, and negotiating the transaction; the costs of measuring to verify the quality of the transacted object; and the costs of valuing the object and paying for it (Baldwin, 2008). Since equity and non-equity alliances are different types of governance structures, some of these mundane transaction costs will be more apparent in one governance form compared to the other: for instance, equity alliances will have higher bureaucratic costs, while non-equity alliances spend time and costs on describing contractual terms and conditions (Sampson, 2005). As firms accumulate experience with a particular governance form, they are able to reduce the mundane transaction costs over time when they choose the same governance form for a new alliance (Ryall and Sampson, 2006). We therefore expect firms with equity alliance experience to use equity alliances again, and firms with non-equity alliance experience to use non-equity alliances again.

The second effect is derived from studies that argue that alliance experience may reduce behavioural uncertainty and the associated opportunistic transaction costs, and consequently firms need to rely less on the strong safeguards of an equity alliance. Experience thus acts as a substitute for equity alliances (Schreiner et al., 2009; Shipilov and Stern, 2016; Teng and Das, 2008). Alliance experience provides firms with collaborative know-how (Simonin, 1997) that enables them to make better judgements on the potential for 
opportunistic behaviour (Gulati et al., 2009). Firms with equity alliance experience have not only dealt with behavioural uncertainty in the past, but their collaborative know-how allows them to reduce behavioural uncertainty in the process and, hence, rely less on strong safeguards in the future (Richards and Yang, 2007).

To empirically analyse the two effects of governance experience on governance choice, we studied 3,724 alliance governance choices made by firms between 2009 and 2011 . These firms have 8,621 earlier experiences with non-equity alliances and 3,486 experiences with equity alliances between 2004 and 2010. We first put our data to the test by replicating the comparative static finding prevalent in received theory that higher behavioural uncertainty is associated with equity alliances. Subsequently we introduce governance experience into TCE's comparative static analysis and our results show that firms are relatively consistent in their alliance governance choices: firms that have experience with non-equity alliances are more likely to choose non-equity alliances again, and firms that have experience with equity alliances are more likely to choose equity again in a subsequent alliance. However, the introduction of governance experience also has an effect on opportunistic transaction costs, which manifests itself in high-uncertainty alliances. Our results show that firms with a large experience with equity alliances are less likely to choose equity again to govern a highuncertainty alliance. This corroborates that alliance experience acts as a substitute for equity governance (Shipilov and Stern, 2016), but only for alliances that are confronted by high behavioural uncertainty and therefore must mitigate opportunistic transaction costs.

The main contribution of our article is to show that governance experience affects governance choices. We offer a better understanding of governance choices by going beyond the traditional static analysis of governance structures. By integrating experience into the analysis, we show that firms choose the same governance structure over time to reduce mundane transaction costs and they rely on their experience to govern an alliance and reduce 
opportunistic transaction costs. We respond to recent studies that argue there is considerable scope for future research to examine how alliance experience and capabilities design safeguards against opportunistic behaviour (e.g. Wang and Rajagopalan, 2014).

\section{THEORY}

\section{Alliance governance: equity alliances versus non-equity alliances}

We distinguish between alliances in which equity is shared and alliances in which no equity is shared. Previous research has highlighted the differences between these two types of alliance governance structures (Gulati and Singh, 1998; Oxley, 1997; Pisano, 1989; Reuer et al., 2016). Equity alliances involve the formation of a separate entity in which each of the partners owns a portion of the equity. The allocation of ownership shares in the new venture aligns incentives among the partners, and an administrative hierarchy of managers oversees day-to-day functioning and addresses contingencies as they arise (Gulati and Singh, 1998). A board of directors is the primary mechanism through which each partner exercises its residual rights of control, and by allocating these rights equity alliances reduce the need for partners to specify all contingencies in their initial agreement (Pisano, 1989; Reuer et al., 2014). In contrast, non-equity alliances do not involve equity sharing or the creation of a new entity (Gulati and Singh, 1998). A key distinguishing governance feature of non-equity alliances is the specification of an incentive alignment in (bilateral) contractual agreements (Oxley, 1997; Reuer and Ariño, 2007). Ongoing activities are jointly coordinated, with all partners working from their own organization, and when contingencies arise, new decisions are negotiated between the partners (Gulati and Singh, 1998). 


\section{Behavioural uncertainty and equity governance}

The received view on governance structures (e.g. Tadelis and Williamson, 2012) has adopted the 'discriminatory alignment hypothesis' that aligns different governance structures to different transactions, so as to minimize transaction costs. In our case, the adaptive capacities of equity or non-equity alliances are matched to the attributes of the transactions, such as behavioural uncertainty. Research on inter-firm collaborations has shown that behavioural uncertainty, defined as the uncertainty of encountering opportunistic behaviour, can explain why firms form complex equity-based arrangements rather than depend on simpler non-equity agreements (e.g. Gulati, 1995; Jolink and Niesten, 2012; Pisano, 1989). Equity alliances possess governance capacities such as additional monitoring rights and administrative controls that provide safeguards against opportunistic behaviour (Niesten and Jolink, 2012; Oxley, 1997; Pangarkar and Klein, 2001; Reuer et al., 2016). In contrast, the capacities of non-equity agreements are a more efficient match for transactions characterized by low or moderate levels of behavioural uncertainty, as Krishnan et al. (2015) concluded in a recent meta-analysis.

In the context of alliances, opportunistic behaviour is defined as "behaviour by a partner firm that is motivated to pursue its self-interest with deceit to achieve gains at the expense of the other alliance members" (Das and Rahman, 2010, p. 57). Deceit by an alliance partner is reflected in calculated efforts to mislead, distort, and disguise information (Niesten and Jolink, 2012; Williamson, 1985). It is easier for an alliance partner to distort and disguise information when the alliance is characterized by asymmetric or unverifiable information $(\mathrm{Li}$, Qian, and Qian, 2013; Wang and Zajac, 2007; Wathne and Heide, 2000). Alliances characterized by information asymmetry - and therefore subject to a higher likelihood of opportunistic behaviour - can involve partners that differ substantially from each other and that are not equally informed about each other's business environment and operations (Wang 
and Zajac, 2007). The research on alliances has linked information asymmetry and a higher potential for opportunistic behaviour to various differences between alliance partners, such as industrial dissimilarity (Das and Rahman, 2010), cultural distance (Chang et al., 2008; Das and Rahman, 2010; Johnson et al., 1996; Lee, 1998; Li et al., 2010; Pangarkar and Klein, 2001) and geographic distance (Li et al., 2010; Reuer and Lahiri, 2014). For instance, crosscultural collaborative arrangements are often replete with misunderstandings and miscommunication (Johnson et al., 1998), thus fostering opportunistic tendencies. Others have also argued the reverse, i.e. that more, and more reliable, information is available for domestic partners and that partner opportunism is lower when alliance members come from similar industries (Das and Rahman, 2010; Pangarkar and Klein, 2001).

In line with the consensus in the alliance literature, we replicate the finding that behavioural uncertainty in alliances is higher when the alliance partners have dissimilar industrial, cultural and national backgrounds, and we expect that alliances characterized by behavioural uncertainty are more often governed by equity alliances. We will replicate these findings with the following hypotheses:

H1. Firms that enter into an alliance characterized by high behavioural uncertainty are more likely to choose an equity governance structure.

Hla. Firms that enter into an alliance with a partner from a different industry are more likely to choose an equity governance structure.

H1b. Firms that enter into an alliance with a partner from a different culture are more likely to choose an equity governance structure.

H1c. Firms that enter into an alliance with a partner from a different country are more likely to choose an equity governance structure. 


\section{Alliance experience and reduction of mundane transaction costs}

While there is an extensive amount of research on the relation between behavioural uncertainty and governance, this is less the case for the relation between alliance experience and governance choices. Studies addressing the latter topic show that firms make discrete governance choices and intentionally accumulate experience with one alliance governance form (Anand et al., 2016). This is due, in part, to the difference in managing an equity alliance compared to managing a non-equity alliance (Anand and Khanna, 2000), but it can also be attributed to the consideration that benefits of governance experience largely accrue from a single governance mode (Gulati et al., 2009). As a consequence, the alliance experience in one governance form will lead to a continued use of that form (Wang and Rajagopalan, 2015). The reasons for accumulating experience with one alliance governance form lie in the substantial differences between equity and non-equity alliances (Gulati and Singh, 1998; Oxley, 1997; Pisano, 1989; Reuer et al., 2016), and firms' adaptive capability to reduce transaction costs over time with increasing experience in one governance form (Ryall and Sampson, 2006).

With respect to equity alliances, Sampson (2005) argues that equity sharing relieves firms from fully specifying alliance activities in a contract, but equity alliances impose more bureaucratic costs on the inter-firm relation. Applying the experience-curve literature, she claims that experience and learning will reduce these bureaucratic costs over time (Sampson, 2005). Rothaermel and Deeds (2006) also apply the notion of experience effects and associated unit-cost reductions to inter-firm relations and highlight that learning effects have also been found to play out in repeated equity alliances.

With respect to non-equity alliances, Ryall and Sampson (2006, p. 207) argue that firms with experience in drafting contracts will specify the rights, obligations, and development processes of new alliance contracts at lower cost. In line with this study, Li et al. 
(2010, p.152) posit that firms experienced in managing non-equity alliances "have learned how to specify, monitor and enforce a contract in non-equity alliances", and "this experience will decrease the transaction cost of future non-equity alliances". In another study on nonequity alliances, Schreiner et al., (2009) argue that alliance capabilities, which develop with an accumulation of alliance experience, mitigate the costs associated with managing interdependence between alliance partners.

Based on these studies, we expect that firms with experience in equity sharing in an alliance will continue choosing equity sharing in a subsequent alliance, to reduce mundane transaction costs. These firms have experience with establishing a new entity, a hierarchical structure and ownership sharing, and their experience enables them to reduce costs in a new equity alliance. Similarly, we expect firms with experience in non-equity alliances to continue choosing the non-equity governance form for a new alliance, also to reduce mundane transaction costs. Their experience with formulating contract terms and negotiating new decisions allows these firms to reduce mundane transaction costs in a new non-equity alliance. We therefore formulate the following two hypotheses:

H2a. Firms that have accumulated more experience with equity sharing in alliances are more likely to choose equity governance for new alliances.

H2b. Firms that have accumulated more experience with non-equity alliances are less likely to choose equity governance for new alliances.

\section{Alliance experience and reduction of opportunistic transaction costs}

Several studies have also observed that alliance experience may lead to a reduction of opportunistic behaviour (e.g. Li et al., 2010; Rahman and Korn, 2014). A variety of explanations have been proposed for this effect, derived from attributes of the alliance and the 
firm. At the alliance level, governance experience enables partners to add more detail to a collaboration to clarify expectations about behaviour in an alliance, which may in turn lower opportunism (Ryall and Sampson, 2006). Prior experience in managing alliances may also enable alliance partners to create stronger bonds and reduce the need for safeguards against opportunistic behaviour (Schreiner et al., 2009). Several studies emphasize that alliance experience allows firms to rely less on equity governance as they learn to deal with alliances and rely more on inter-firm trust (Inkpen and Currall, 2004; Subramanian and Soh, 2016; Teng and Das, 2008). As inter-firm trust will make opportunistic behaviour less likely, trust reduces the required safeguards and effectively lowers opportunistic transaction costs. Alliance experience and capabilities can therefore act as a substitute for equity governance (Teng and Das, 2008).

At the firm level, scholars have argued that alliance experience results in a positive reputation for a firm, which curtails the firm's opportunistic behaviour in alliances (Pangarkar, 2003; Ryall and Sampson, 2006). Experience also provides firms with alliance capabilities that increase their awareness of the hazard of opportunism in alliances (Gulati et al., 2009). These capabilities enable firms to prevent or counteract opportunistic behaviour by their partners that would involve unfair or asymmetric value capture (Wang and Rajagopalan, 2015). Firms with collaborative know-how are able to search out reliable partners, effectively anticipate contingencies and design bonding mechanisms to discourage opportunism (Chang et al., 2008, p. 301). It has also been noted that these effects of alliance experience are mainly observed in equity alliances and none in non-equity arrangements (Anand and Khanna, 2000), because firms with equity alliance experience have dealt with behavioural uncertainty in the past (Richards and Yang, 2007).

We contribute to this field of research by studying firms with equity alliance experience and expect they are less likely to choose that same governance mode (equity 
sharing) in subsequent alliances characterized by high behavioural uncertainty. We thus expect that firms substitute experience for equity governance, and rely on their experience to reduce opportunistic transaction costs. This effect will only be observed for high uncertainty alliances, because opportunistic transaction costs can only be reduced when opportunistic behaviour prevails. We therefore formulate the following hypotheses:

H3: As experience with equity increases, the need for equity governance for alliances characterized by high behavioural uncertainty declines.

H3a: As experience with equity increases, the need for equity governance for alliances with partners from different industries declines.

H3b: As experience with equity increases, the need for equity governance for alliances with partners from different cultures declines.

H3c: As experience with equity increases, the need for equity governance for alliances with partners from different countries declines.

\section{METHOD}

\section{Sample and data}

To include data on equity and non-equity governance structures, we combined two sets of data from the Thomson Reuters SDC Platinum database on inter-firm relations: one on alliances in which equity is shared and another on alliances in which no equity is shared. From these data sets we removed alliances that were classified as 'letters of intent', 'pending' or 'terminated', and we only included alliances that were classified as 'completed' or 'signed'. We also removed alliances with more than two partners and only included bilateral alliances. This allowed us to use measures of dissimilarity and distance between alliance partners that were the same across all the alliances in our dataset and thus reflected 
behavioural uncertainty in the same way. Furthermore, we excluded alliances with non-profit organizations. We also removed alliances with undisclosed partners, as we required the information of the alliance partner to calculate experience and to link the SDC database to information in the Thomson One database. Our dataset contains information on 3,724 alliance choices between 2009 and 2011, and it includes 2,040 choices for equity governance structures and 1,684 choices for non-equity governance structures.

\section{Variables and measures}

Our dependent variable Equity Governance Structure reflects the governance choice of a firm entering into an alliance with another firm. It captures the likelihood that firms choose an equity governance structure for their inter-firm relation. The dependent variable is thus a binary variable, with 1 reflecting the choice of an equity governance structure and 0 reflecting the choice of a non-equity governance structure.

We include two independent variables on alliance experience: Experience with Equity Alliances and Experience with Non-equity Alliances. We consider these two types of accumulated experience for a five-year period using the SDC database (Ryall and Sampson, 2006). We consider experience with equity or non-equity alliances in the years from 2004 until 2008 for alliances established in 2009, from 2005 until 2009 for alliances established in 2010, and from 2006 until 2010 for alliances established in 2011. When a firm is part of a larger holding, we include the experience of the holding company in the amount of experience of the firm because we assume that alliance knowledge is also stored at the holding level and may be transferred to subsidiaries when they enter into alliances (Heimeriks et al., 2007; Inkpen, 1998). The distributions of these two variables displayed a positive skewness, and we therefore redefined them using the natural log transformation (Zollo et al., 2002). 
Furthermore, as a proxy for behavioural uncertainty we include three independent variables to capture the dissimilarity of alliance partners. We use codes from the Standard Industrial Classification (SIC) system to measure the Industry Dissimilarity of Alliance Partners (as used extensively by others, e.g., Cui and Kumar, 2012; Lin et al., 2009; Reuer and Koza, 2000; Reuer and Lahiri, 2014; Villalonga and McGahan, 2005; Wang and Zajac, 2007). This is an ordinal variable with five categories of increasing dissimilarity. Firms are in the same industry when they have the same (primary) four-digit code, they are in a different industry but the same industry group when the last digit is different, they are in a different industry group but the same major group when the last two digits are different, they are in a different major group but the same division when the last three digits are different, and they are in a different division when the SIC codes are entirely different. The base level of this ordinal variable is the category of alliance partners that are in the same industry (i.e., they have the same four-digit code). We chose this category as the base level because it allows us to compare alliance partners in the four categories that reflect dissimilarity (i.e., partners in different industries, different industry groups, different major groups and different divisions) to alliance partners that are in the same industry and thus test the relation between industry dissimilarity (as a first proxy for behavioural uncertainty) and the choice of equity governance.

Cultural Distance between Alliance Partners is determined using Hofstede's six-item measure, which includes power distance, individualism, masculinity, uncertainty avoidance, long-term orientation and indulgence. We calculate a score for each alliance partner's national culture and subtract the scores to obtain the cultural distance using the following formula:

$$
\begin{gathered}
C D=\sqrt{ }\left((P D 1-P D 2)^{2}+(\operatorname{Indiv} 1-\operatorname{Indiv} 2)^{2}+(M 1-M 2)^{2}+(U A 1-U A 2)^{2}\right. \\
\left.+(\text { LTO } 1-\text { LTO2 })^{2}+(\text { Indul } 1-\text { Indul } 2)^{2}\right)
\end{gathered}
$$

in which $P D$ refers to power distance, Indiv to individualism, $M$ to masculinity, $U A$ to 
uncertainty avoidance, LTO to long-term orientation, and Indul to indulgence (Minkov and Hofstede, 2011). An increase in the value of this measure describes an increase in cultural distance between the alliance partners.

Country Dissimilarity of Alliance Partners is a binary variable, and it is coded as 0 when the country of the two partners is the same and as 1 when the country of the two partners is different. While there are other measures that reflect dissimilarity in terms of geography, such as geographic distance (Reuer and Lahiri, 2014), country dissimilarity is a better reflection of differences that are pertinent to governance choices in institutional environments across countries (Oxley and Sampson, 2004). These differences are likely to be a source of behavioural uncertainty and are therefore relevant when predicting a firm's choice of equity governance.

We include three interaction terms to be able to test hypotheses 3-3c. These terms multiply each of the three variables reflecting behavioural uncertainty (industry dissimilarity, cultural distance and country dissimilarity) with experience with equity alliances. An increase in the value of the interaction terms describes increasing levels of dissimilarity / distance and increasing experience with equity.

We also include six control variables. A first control variable is Alliance Purpose. Pangarkar and Klein (2001) find a significant impact of the purpose of the alliance formation on the choice of the governance structure. The SDC database offers an activity description and a more elaborate deal text for each alliance. Based on these descriptions, we categorized each alliance into one of three categories: $R \& D$, production, and marketing. An alliance is coded as an R\&D alliance when the SDC description refers to research, development or improvement of a product or service or to the discovery or creation of a new product or service. The alliance is coded as a production alliance when the description refers to producing, making, assembling, constructing or manufacturing or to establishing, building or 
operating a plant or production facility. The remaining alliances are coded as marketing alliances. Occasionally, the deal texts indicate that an alliance is involved in more than one stage of the value chain. To reduce the number of categories for this variable, we only code the first stage of the value chain, with $R \& D$ preceding production, and production preceding marketing.

Technology Transfer is a binary variable, with 1 indicating that technology transfer is part of the alliance and 0 indicating that no technology transfer occurs. This variable is included in the SDC database.

Industry of the Alliance is included as a control variable because firms in certain industries may be more inclined to choose equity governance. Gulati and Singh (1998) argue that firms in industries with a loose appropriability regime are subject to involuntary leakage of their profits and may therefore prefer equity-based governance structures. We grouped the primary SIC code of the alliances into 10 divisions (www.osha.gov) representing a collection of industries: agriculture, forestry and fishing (SIC codes 0111-0971); mining (1011-1499); construction (1521-1799); manufacturing (2011-3999); transportation, communications, electric, gas, and sanitary services (4011-4971); wholesale trade (5012-5199); retail trade (5211-5999); finance, insurance, and real estate (6000-6799); services (7011-8999); and public administration (9111-9721).

Venture Capital Backing of Alliance Partners is included as a binary control variable, and it measures whether an alliance partner is backed by venture capital (VC). We include this control variable because previous research has demonstrated that VC-backed firms are less likely to form an equity alliance (Jolink and Niesten, 2016). Information on the VC backing of partners was obtained from Thomson One by manually searching for the names of the alliance partners (obtained from the SDC database) in Thomson One's information on venture deals. The partners are coded as VC backed if they receive venture capital in the year 
of the announcement date of the collaboration or in any of the four years preceding the year of the announcement (Wang et al., 2012).

Firms may have tax reasons to initiate an equity alliance (PWC, 2012); therefore, we include a binary variable that indicates whether an alliance or the partners are located in a Tax Haven using the list of countries from Gravelles (2015).

To control for unobserved heterogeneity during the study period (2009-2011), we include a control variable reflecting the Year of the Alliance (e.g., Lin et al., 2009; Reuer and Lahiri, 2014).

\section{Estimation methods}

Our dataset contains information on firms' choices about alliance governance for the period 2009 until 2011, and it includes partially overlapping and successive periods of alliance experience (2004-2008; 2005-2009; 2006-2010). Since firms can initiate more than one alliance in the time period of our study, some firms are included more than once in our dataset. To cope with this unbalanced panel and the correlation between repeated observations for firms over time, we used generalized estimating equations (GEE) and clustered at the firm level. GEE has been used in prior studies with models containing clusters of firms (e.g., Hambrick and Quigley, 2014). The interpretation of odds ratios in models estimated with GEE is the same as in standard logit models. The advantage of GEE is that it accounts for correlations due to repeated measurements or clusters in the data (Lalonde et al., 2013). Our six models were estimated using the xtgee function in Stata 14. As the dependent variable was a binary variable, we specified a binary logit model. Using the linktest command in Stata, we confirmed that logit is the appropriate link function and that there is a linear relationship between the independent variables and the logit of the dependent variable. We used an exchangeable correlation structure because the observations within each cluster are correlated, 
unlike the observations from different clusters. All the models were estimated using robust standard errors to provide a conservative test of our hypotheses.

\section{RESULTS}

Table I provides descriptive statistics of the variables. Table II reports the association coefficients and reports the Cramer's V, because we include several categorical variables. Table III provides the results and includes the GEE model containing only the control variables (model 1) and the five GEE models containing the control and independent variables (models 2-6), all of which predict the likelihood that an alliance has equity governance. Model 2 includes the cultural distance between partners and model 3 includes the country dissimilarity of partners. We introduce these two independent variables in separate models because of the high correlation between them (see Table II). Models 4-6 include the interaction terms that multiply each of the three types of dissimilarity with experience with equity. The six models are statistically significant (see table III).

We find support for the replication of the findings prevalent in TCE (hypotheses 1-1c), which associate higher behavioural uncertainty with a greater likelihood of equity governance. Behavioural uncertainty is measured by industrial dissimilarity, cultural distance and country dissimilarity. The base category of the ordinal variable industry dissimilarity of partners is alliance partners in the same industry. The odds ratios of the categories that reflect dissimilarity between partners therefore represent the factor change in the odds of choosing equity governance when compared to alliance partners in the same industry. The results show that firms with partners in a different industrial division, a different major group, and a different industry group have higher odds of choosing equity. In model 2 , the odds of choosing equity are 1.446 times higher for partners in a different division ( $\mathrm{p}$-value is lower than 0.000), 2.141 times higher for partners in a different major group ( $\mathrm{p}$-value is lower than 
0.000), and 1.439 times higher for partners in a different industry group ( $\mathrm{p}$-value $=0.013$ ) The results also show that the odds of choosing equity increase by a factor of 1.034 when the cultural distance between partners increases by 1 (p-value is lower than 0.000). Model 3 reports results that are consistent with the findings of model 2. This model does not include cultural distance but includes country dissimilarity of partners instead. The odds of choosing equity are 1.384 times higher for alliance partners from different countries than for partners from the same country (p-value is lower than 0.000). Models 2 and 3 thus offer consistent results for the relation between higher behavioural uncertainty and the choice of equity governance (for the three different specifications of uncertainty).

The results of model 2 (and model 3) also show that we find support for hypotheses 2a and $2 \mathrm{~b}$, which associate experience with equity with a higher likelihood of choosing equity governance, and non-equity experience with a lower likelihood of choosing equity governance. The odds of choosing equity governance increase by a factor of $1.690(1.726)$ when the natural logarithm of experience with equity alliances increases by 1 . The odds ratio of experience with non-equity alliances is $0.579(0.585)$, indicating that a one-unit increase in the natural logarithm of non-equity alliance experience reduces the odds of choosing equity governance by 42.1 (41.5) per cent. The p-values of both variables are below 0.000 . These findings suggest that firms take the reduction of mundane transaction costs into consideration in their governance decisions because they choose the same governance structure in successive alliances.

\section{Insert Table I about here}

Insert Table II about here

\section{Insert Table III about here}


Model 4 includes the interaction term that multiplies industry dissimilarity and experience with equity. The odds ratio of this term is 0.988 with a p-value of 0.030 . This result confirms hypothesis $3 \mathrm{a}$, and shows that firms that form alliances with a partner in a different industry and that have a large experience with equity alliances are less likely to enter into an equity alliance. Models 5 and 6 include the interaction terms that multiply cultural distance and country dissimilarity (respectively) with experience with equity. The odds ratios of these terms show similar results and confirm hypotheses $3 b$ and $3 c$. Firms that form alliances with partners from a different country and at a large cultural distance and that have experience with equity alliance are less likely to enter into an equity alliance. These results of models 4-6 confirm our claims that firms use their experience as a substitute for equity governance to reduce opportunistic costs in an alliance.

We also offer graphical representations of these results and a discussion in terms of probabilities. The probabilities are intuitively more meaningful and less prone to misinterpretation than odds ratios (Hoetker, 2007; Reuer and Lahiri, 2014). Figure 1 compares the effects of equity alliance experience on equity governance for alliance partners in the same industry and for partners in a different industry (as proxies for low and high levels of behavioural uncertainty, respectively). When generating the margins for experience with equity and the different categories of industry dissimilarity displayed in figure 1 (or cultural distance and country dissimilarity in figures 2-3), we set the other variables in the GEE model at the mean. The figure illustrates that when equity alliance experience increases from 0 to 32 (natural $\log$ of 32 is 3.47 ), the firms' probability of choosing equity governance increases by 39.2 per cent when the partners come from the same industry. However, with increasing equity alliance experience, the probability that firms choose equity governance increases only by 28.7 per cent when the partners come from a different major industrial group, where the maximum change could have been 35.4 per cent. This means that experienced firms will rely 
less on equity governance and use their experience as a substitute for equity governance in high behavioural uncertainty alliances, because in these alliances they are able to reduce opportunistic transaction costs. We observe the same patterns for other proxies of behavioural uncertainty, including cultural distance and country dissimilarity. Figure 2 illustrates that partners with an above-average cultural distance have a lower increase in the probability of choosing equity with increasing experience than partners with below-average cultural distance. The change in probability of choosing equity for firms with an above average cultural distance is 32.5 per cent, whereas the maximum change could have been 43 per cent. Figure 3 shows that firms with partners from a different country have a lower increase in the probability of choosing equity with increasing experience than firms with partners from the same country. The change in probability of choosing equity for firms with a partner from a different country is 34.5 per cent, whereas the maximum change could have been 45.4 per cent. This is again due to experience acting as a substitute for equity governance for alliances characterized by a higher behavioural uncertainty and to the potential for reducing opportunistic transaction costs in these high-uncertainty alliances. These results provide support for hypotheses 3-3c.

With respect to the control variables, the six models show that technology transfer in an alliance and the $\mathrm{VC}$ backing of alliance partners are linked to lower odds of choosing equity, whereas alliances in tax havens and in industries such as mining, construction, transportation and finance are linked to higher odds of choosing equity. The control variable alliance purpose shows that production alliances are more likely to be governed by equity when compared to $R \& D$ alliances.

\section{Insert Figure 1 about here}

\section{Insert Figure 2 about here}




\section{Insert Figure 3 about here}

\section{Robustness}

We checked for multicollinearity of the independent and control variables. The variance inflation factor (VIF) of cultural distance and country dissimilarity is 2.93 , which is the reason we include these two variables in two separate models. When we exclude either cultural distance or country dissimilarity, the VIF is never higher than 1.33 (mean VIF is 1.12 ), which indicates that there are no problems with multicollinearity between the other variables.

The unit of analysis in this study is the firm, reflecting the governance choice that firms make when entering into an alliance with another firm. However, our decision to study firm choices in an alliance context (as opposed to considering the alliance as the unit of analysis) has some consequences for the estimation of our model, particularly in relation to the three independent variables: Industry Dissimilarity, Cultural Distance and Country Dissimilarity. For instance, when two firms in different industries decide to enter into an equity alliance, the data record two choices and thus two observations linking industry dissimilarity to equity. Our focus on firm choices may therefore underestimate the standard errors and overestimate the significance of the relation between the independent and dependent variables. To correct for this, we ran additional logit models and clustered the observations on the governance choice of two firms (i.e., the two alliance partners) at the level of the bilateral alliance. The models are estimated with robust standard errors. The results are consistent with the results reported in table III and figures 1-3. 


\section{DISCUSSION}

\section{Findings and contribution}

This article set out to study the effect of alliance experience on alliance governance choices to determine when governance choices can best be explained by a reduction in mundane transaction costs and when they can be attributed to a reduction in opportunistic transaction costs. Our findings show that firms are relatively consistent in their choice of alliance governance structure over time. Firms that have experience with equity alliances choose equity in a new alliance, and firms that have experience with non-equity alliances choose a non-equity alliance, when mundane transaction costs can be reduced over time. Our results also show that the level of behavioural uncertainty involved in an alliance affects the impact of alliance experience on governance. As their experience increases, firms display a smaller increase in the probability of choosing equity when an alliance is characterized by high behavioural uncertainty than when it is characterized by low behavioural uncertainty. This indicates that experience can function as a safeguard in high-uncertainty alliances and enable firms to reduce opportunistic transaction costs in an alliance.

By combining the literatures on alliance experience and governance, our study offers several contributions to each of these fields and, more broadly, provides new understanding for research on TCE, organizational learning and the field of strategic management. First, our study is one of the first to explore the links between experience and governance choices in detail by analysing more than 12,000 firm experiences with equity and non-equity alliances. We show that governance choices may depend on an efficient alignment between transaction attributes and governance forms but that they are also influenced by earlier governance choices made by firms. In effect, governance choices are strongly influenced by a firm's past decisions on governance. Our study therefore contributes to the emerging field of alliance dynamics and shows that a firm's previous governance choices have an impact on its current 
alliance decisions (Reuer et al., 2016). This finding illustrates and confirms the observation that the combination of an experience or learning perspective and TCE can be fruitful (Argyres and Mayer, 2007).

Second, we demonstrate that firms are more likely to choose the same governance structure over time. These choices by firms to reuse or reapply the same governance structure in successive alliances have been explained in this article by firms' willingness to reduce the mundane transaction costs of establishing and managing the governance of inter-firm relations. The analysis of these mundane transaction costs in the context of alliance governance choices has largely been ignored in previous studies.

Third, our study sheds light on the trade-off between mundane and opportunistic transaction costs. When we compare alliances characterized by high behavioural uncertainty to alliances with lower uncertainty, the former exhibit a moderate increase in their probability of choosing equity as their experience with equity increases. In high-uncertainty alliances, experience with equity thus acts as a substitute safeguard for equity governance. In lowuncertainty alliances, firms encounter less opportunistic behaviour, which may suggest that they are mainly concerned with reducing mundane transaction costs. In high-uncertainty alliances, firms are aware of opportunistic transaction costs and realize that experience can replace the need for equity. When firms rely on experience as a substitute for equity governance to reduce opportunistic transaction costs, they forgo reducing mundane transaction costs. This finding supports the assertion of Argyres and Mayer (2007) that alliance experience and capabilities may act as a shift parameter and thus affect firms' governance choices.

Finally, our results contribute to the literature on the impact of alliance capabilities on different outcome variables, such as performance, innovation, alliance formation, and governance (Heimeriks et al., 2007; Schreiner et al., 2009). Several studies in this field have 
argued that a better understanding of the impact of alliance capabilities on performance can be achieved by studying the intermediate impact of capabilities on alliance attributes (Ambrosini and Bowman, 2009; Niesten and Jolink, 2015). Our study demonstrates that the impact of alliance experience on governance depends on the transactional attribute of behavioural uncertainty.

\section{Limitations}

Some limitations must also be mentioned. First, the focus on the dyadic nature of inter-firm collaboration has supported the analysis of this article, illustrating the persistent governance choices of firms over time. By focusing on bilateral and dyadic alliances, we abstracted from the complexities of governance choices in multi-party alliances and governance choices of firms in the context of their alliance portfolio. Future research could study the impact of experience on the governance choices of firms by considering the governance structures of a firm's current set of alliances including alliances involving more than one partner.

Second, we have used the concept of transaction costs - including the differentiation between "mundane" and "opportunistic" transaction costs - as it has been described in the strategic management literature over the past 40 years. Although examples of both types of transaction costs have been provided, this approach only offers proxies for transaction costs by analysing governance choices over time. With transaction costs as the latent variable, this limitation can be overcome only by delving deeper into the actual transaction costs for each alliance.

Third, our data on alliance experience are limited to five years prior to the announcement date of an alliance, following the convention that the effects of experience expire after a certain number of years. Further specifying the nature of alliance experience and clarifying its consequences can address this limitation. The five-year period may differ 
across industries or technologies: experience with alliances established more than five years ago may still be relevant and used in stable industries, but this may not be the case for hightech and other highly dynamic industries. In addition, some firms may be very capable of codifying, storing, and using alliance experience, whereas others may make no explicit attempt to accumulate alliance capabilities. These differences between firms will also affect the number of alliance experience years that researchers should consider.

\section{CONCLUSION}

This article responds to the call for further study of alliance dynamics that may impact or shift alliance decisions (Das and Teng, 2002; Reuer et al., 2016; Wang and Rajagopalan, 2014). We have studied the impact of alliance experience on alliance governance, and our findings demonstrate that governance decisions at a single point in time do not depend only on the characteristics of the transaction, as in TCE, but are also informed by earlier governance decisions. We have shown that firms reuse the same governance structure in successive alliances when mundane transaction costs can be reduced over time. This issue is far from trivial, as many governance decisions are not first-time decisions, and the sequence of alliance decision-making introduces continuity in governance choices.

In this article, we have also demonstrated the importance of behavioural uncertainty in a time context and how this identifies alliance governance and alliance experience as shift parameters. In the case of no- (or low-) uncertainty alliances and the relative absence of opportunistic transaction costs, experience will reduce mundane transaction costs; however, in the presence of high behavioural uncertainty in an alliance, experience can reduce opportunistic transaction costs. In the latter case, alliance experience serves as a substitute for equity governance, and firms rely on their experience to reduce opportunistic transaction costs. We conclude that our analysis of governance experience complements the static 
theoretical perspectives of alliance decision-making and reveals avenues for future research on the impact of alliance capabilities on governance choices over time.

\section{ACKNOWLEDGMENTS}

We thank Joseph Lampel and John Hagedoorn for their insightful and constructive suggestions on earlier versions of this manuscript. We also greatly benefitted from comments received at the 2016 SMS, EURAM and BAM conferences, internal seminars at the Alliance Manchester Business School, and the 2015 GCW conference. This research did not receive any specific grant from funding agencies in the public, commercial, or not-for-profit sectors.

\section{REFERENCES}

Ambrosini, V., Bowman, C., 2009. What are dynamic capabilities and are they a useful construct in strategic management? International Journal of Management Reviews, 11, 29-49. Anand, B.N., Khanna, T., 2000. Do firms learn to create value? The case of alliances. Strategic Management Journal, 21, 295-315.

Anand, J., Mulotte, L., Ren, C.R., 2016. Does experience imply learning? Strategic Management Journal, 37, 1395-1412.

Argyres, N., Mayer, K., 2007. Contract design as a firm capability: An integration of learning and transaction cost perspectives. Academy of Management Review, 32, 1060-1077.

Baldwin, C.Y., 2008. Where do transactions come from? Modularity, transactions, and the boundaries of firms. Industrial and Corporate Change, 17, 155-195.

Chang, S.-C., Chen, S.-S., Lai, J.-H., 2008. The effect of alliance experience and intellectual capital on the value creation of international strategic alliances. Omega, 36, 298-316.

Cui, A.S., Kumar, M.V.S., 2012. Termination of related and unrelated joint ventures: A contingency approach. Journal of Business Research, 65, 1202-1208. 
Das, T.K., Rahman, N., 2010. Determinants of partner opportunism in strategic alliances: A conceptual framework. Journal of Business and Psychology, 25, 55-74.

Das, T.K., Teng, B.-S., 2002. The dynamics of alliance conditions in the alliance development process. Journal of Management Studies, 39, 725-746.

Faems, D., Janssens, M., Madhok, A., Van Looy, B., 2008. Toward an integrative perspective on alliance governance: Connecting contract design, trust dynamics, and contract application. The Academy of Management Journal, 51, 1053-1078.

Gravelles J., 2015. Tax havens: International tax avoidance and evasion. Congressional Research Service, Washington.

Gulati, R., 1995. Social structure and alliance formation patterns: A longitudinal analysis. Administrative Science Quarterly, 40, 619-652.

Gulati, R., Singh, H., 1998. The architecture of cooperation: managing coordination costs and appropriation concerns in strategic alliances. Administrative Science Quarterly, 43, 781-814.

Gulati, R., Lavie, D., Singh, H., 2009. The nature of partnering experience and the gains from alliances. Strategic Management Journal, 30, 1213-1233.

Hambrick, D.C., Quigley, T.J., 2014. Toward more accurate contextualization of the CEO effect on firm performance. Strategic Management Journal, 35, 473-491.

Heimeriks, K., Duysters, G., Vanhaverbeke, W., 2007. Learning mechanisms and differential performance in alliance portfolios. Strategic Organization, 5, 373-409.

Hennart, J.-F., 1988. A transaction costs theory of equity joint ventures. Strategic Management Journal, 9, 361-374.

Hennart, J.-F., 1991. The transaction cost theory of joint ventures: An empirical study of Japanese subsidiaries in the United States. Management Science, 37, 483-497.

Hoetker, G., 2007. The use of logit and probit models in strategic management research: Critical issues. Strategic Management Journal, 28, 331-343. 
Inkpen, A.C., 1998. Learning, knowledge acquisition, and strategic alliances. European Management Journal, 16, 223-229.

Inkpen, A.C., Currall, S.C., 2004. The coevolution of trust, control, and learning in joint ventures. Organization Science, 15, 586-599.

Johnson, J.L., Cullen, J.B., Sakano, T., 1996. Opportunistic tendencies in IJVs with the Japanese: The effects of culture, shared decision making, and relationship age. International Executive, 38, 79-94.

Jolink, A., Niesten, E., 2012. Recent qualitative advances on hybrid organizations: Taking stock, looking ahead. Scandinavian Journal of Management, 28, 149-161.

Jolink, A., Niesten, E., 2016. The impact of venture capital on governance decisions in collaborations with start-ups. Small Business Economics, 47, 331-344.

Krishnan, R., Geyskens, I., Steenkamp, J.B.E.M., 2016. The effectiveness of contractual and trust-based governance in strategic alliances under behavioural and environmental uncertainty. Strategic Management Journal, 37, 2521-2542.

Lalonde, T.L., Nguyen, A.Q., Yin, J., Irimata, K., Wilson, J.R., 2013. Modeling correlated binary outcomes with time-dependent covariates. Journal of Data Science, 11, 715-738.

Langlois, R.N., 2006. The secret life of mundane transaction costs. Organization Studies, 27, $1389-1410$.

Li, N., Boulding, W., Staelin, R., 2010. General alliance experience, uncertainty, and marketing alliance governance mode choice. Journal of the Academy Marketing Science, 38, $141-158$.

Li, L., Qian, G., Qian, Z., 2013. Do partners in international strategic alliances share resources, costs, and risks? Journal of Business Research, 66, 489-498.

Lin, Z., Yang, H., Arya, B., 2009. Alliance partners and firm performance: Resource complementarity and status association. Strategic Management Journal, 30, 921-940. 
Madhok, A., Keyhani, M., Bossink, B., 2015. Understanding alliance evolution and termination: Adjustment costs and the economics of resource value. Strategic Organization, $13,91-116$.

Mudambi, S., Tallman, S., 2010. Make, buy or ally? Theoretical perspectives on knowledge process outsourcing through alliances. Journal of Management Studies, 47, 1434-1456.

Minkov, M., Hofstede, G., 2011. The evolution of Hofstede's doctrine. Cross Cultural Management: An International Journal. 18, 10-20.

Niesten, E., Jolink, A., 2012. Incentives, opportunism and behavioural uncertainty in electricity industries. Journal of Business Research, 65, 1031-1039.

Niesten, E., Jolink, A., 2015. The impact of alliance management capabilities on alliance attributes and performance: A literature review. International Journal of Management Reviews, 17, 69-100.

Oxley, J.E., 1997. Appropriability hazards and governance in strategic alliances: A transaction cost approach. Journal of Law, Economics, \& Organization, 13, 387-409.

Oxley, J.E., Sampson, R.C., 2004. The scope and governance of international R\&D alliances. Strategic Management Journal, 25, 723-749.

Pangarkar, N., 2003. Determinants of alliance duration in uncertain environments: The case of the biotechnology sector. Long Range Planning, 36, 269-284.

Pangarkar, N., Klein, S., 2001. The impacts of alliance purpose and partner similarity on alliance governance. British Journal of Management, 12, 341-353.

Pisano, G.A., 1989. Using equity participation to support exchange: Evidence from the biotechnology industry. Journal of Law, Economics, \& Organization, 5, 109-126.

PWC, 2012. Navigating joint ventures and business alliances. Success factors in executing complex arrangements that are challenging to negotiate, operate, monitor and exit. PWC, London. 
Rahman, N., Korn, H., 2014. Alliance longevity: Examining relational and operational antecedents. Long Range Planning, 47, 245-261.

Reuer, J.J., Ariño, A., 2007. Strategic alliance contracts: dimensions and determinants of contractual complexity. Strategic Management Journal, 28, 313-330.

Reuer, J.J., Ariño, A., Poppo, L., Zenger, T., 2016. Alliance governance. Strategic Management Journal, 37, E37-E44.

Reuer, J.J., Klijn, E., Lioukas, C.S., 2014. Board involvement in international joint ventures. Strategic Management Journal, 35, 16261-644.

Reuer, J.J., Koza, M.P., 2000. Asymmetric information and joint venture performance: theory and evidence for domestic and international joint ventures. Strategic Management Journal, 21, $81-88$.

Reuer, J.J., Lahiri, N., 2014. Searching for alliance partners: Effects of geographic distance on the formation of R\&D collaborations. Organization Science, 25, 283-298.

Richards, M., Yang, Y., 2007. Determinants of foreign ownership in international R\&D joint ventures: Transaction costs and national culture. Journal of International Management, $13,110-130$.

Rothaermel, F., Deeds, D., 2006. Alliance type, alliance experience and alliance management capability in high-technology ventures. Journal of Business Venturing, 21, 429- 460.

Ryall, M., Sampson, R.C., 2006. Do prior alliances influence alliance contract structure? in: Ariño, A., Reuer, J.J. (Eds), Strategic Alliances. Palgrave MacMillan, Houndsmills, pp. 206216.

Sampson, R.C., 2004. The cost of misaligned governance in R\&D alliances. Journal of Law, Economics, \& Organization, 20, 484-526.

Sampson, R.C., 2005. Experience effects and collaborative returns in R\&D alliances. Strategic Management Journal, 26, 1009-1031. 
Schreiner, M., Kale, P., Corsten, D., 2009. What really is alliance management capability and how does it impact alliance outcomes and success? Strategic Management Journal, 30, 13951419.

Shipilov, A., Stern, I., 2016. Practical advice on how to unlock value from your alliances. Strategic Management Journal, 37, E45-E53.

Simonin, B.L., 1997. The importance of collaborative know-how: An empirical test of the learning organization. Academy of Management Journal, 40, 1150-1174.

Subramanian, A., Soh, P.-H., 2016. Linking alliance portfolios to recombinant innovation: The combined effects of diversity and alliance experience. Long Range Planning, in press.

Tadelis, S., Wiliamson, O.E., 2012. Transaction Cost Economics, in: Gibbons, R., Roberts, J., (Eds), The Handbook of Organizational Economics, Princeton University Press, Princeton, pp. 159-190.

Teng, B., Das, T.K., 2008. Governance structure choice in strategic alliances: The roles of alliance objectives, alliance management experience, and international partners. Management Decision, 46, 725-742.

Villalonga, B., McGahan, A.M., 2005. The choice among acquisitions, alliances, and divestitures. Strategic Management Journal, 26, 1183-1208.

Wang, L., Zajac, E.J., 2007. Alliance or acquisition? A dyadic perspective on interfirm resource combinations. Strategic Management Journal, 28, 1291-1317.

Wang, H., Wuebker, R.J., Han, S., Ensley, M.D., 2012. Strategic alliances by venture capital backed firms: an empirical examination. Small Business Economics, 38, 179-196.

Wang, Y., Rajagopalan, N., 2014. Alliance capabilities: Review and research agenda. Journal of Management, 41, 236-260.

Wathne, K., Heide, J., 2000. Opportunism in interfirm relations: forms, outcomes, and solutions. Journal of Marketing, 64, 36-51. 
Williamson, O.E., 1985. The Economic Institutions of Capitalism. Free Press, New York.

Williamson, O.E., 1996. The Mechanisms of Governance. Oxford University Press, Oxford.

Zollo, M., Reuer, J.J., Singh, H., 2002. Interorganizational routines and performance in strategic alliances. Organization Science, 13, 701-713. 
Table I. Descriptive statistics

\begin{tabular}{|c|c|c|c|c|}
\hline Variables & Measurement Scale & Frequency / Mean & Min & Max \\
\hline Equity & Binomial & $\begin{array}{l}\text { No equity: } 1,684 \\
\text { Equity: } 2,040\end{array}$ & 0 & 1 \\
\hline $\begin{array}{l}\text { Experience with } \\
\text { equity alliances }\end{array}$ & Count & Mean: 0.936 & 0 & 32 \\
\hline $\begin{array}{l}\text { Experience with non- } \\
\text { equity alliances }\end{array}$ & Count & Mean: 2.315 & 0 & 110 \\
\hline Industry dissimilarity & Ordinal & $\begin{array}{l}\text { Different division: } 1,588 \\
\text { Different major group: } 544 \\
\text { Different industry group: } 376 \\
\text { Different industry: } 322 \\
\text { Same industry: } 894\end{array}$ & 1 & 5 \\
\hline Cultural distance & Continuous & Mean: 7.336 & 0 & 30.388 \\
\hline Country dissimilarity & Binomial & $\begin{array}{l}\text { Different country: } 2,254 \\
\text { Same country: } 1,470\end{array}$ & 0 & 1 \\
\hline Alliance purpose & Nominal & $\begin{array}{l}\text { Production: } 902 \\
\text { Offering products and services: } 1,978 \\
\text { Research and development: } 844\end{array}$ & 1 & 3 \\
\hline Technology transfer & Binomial & $\begin{array}{l}\text { No transfer: } 3,574 \\
\text { Transfer: } 150\end{array}$ & 0 & 1 \\
\hline Industry of alliance & Nominal & $\begin{array}{l}\text { Agriculture, forestry and fishing: } 12 \\
\text { Mining: } 386 \\
\text { Construction: } 78 \\
\text { Manufacturing: } 1,114 \\
\text { Transportation and communication: } 380 \\
\text { Wholesale: } 168 \\
\text { Retail: } 88 \\
\text { Finance, insurance and real estate: } 428 \\
\text { Services: } 1,056\end{array}$ & 1 & 10 \\
\hline $\begin{array}{l}\mathrm{VC} \text { backing of } \\
\text { partners }\end{array}$ & Binomial & $\begin{array}{l}\text { VC-backing: } 175 \\
\text { No VC-backing: } 3,549\end{array}$ & 0 & 1 \\
\hline Tax haven & Binomial & $\begin{array}{l}\text { Tax haven: } 364 \\
\text { No tax haven: } 3,360\end{array}$ & 0 & 1 \\
\hline Year of alliance & Nominal & $\begin{array}{l}\text { 2009: } 1,442 \\
\text { 2010: } 692 \\
\text { 2011: } 1,590\end{array}$ & 2009 & 2011 \\
\hline
\end{tabular}


Table II. Association coefficients (Cramer's V)

\begin{tabular}{|c|c|c|c|c|c|c|c|c|c|c|c|c|}
\hline & Equity & $\begin{array}{l}\text { Experience } \\
\text { with equity } \\
\text { alliances }\end{array}$ & $\begin{array}{l}\text { Experience } \\
\text { with non- } \\
\text { equity } \\
\text { alliances }\end{array}$ & $\begin{array}{l}\text { Industry } \\
\text { dissimilarity }\end{array}$ & $\begin{array}{l}\text { Cultural } \\
\text { distance }\end{array}$ & $\begin{array}{l}\text { Country } \\
\text { dissimilarity }\end{array}$ & $\begin{array}{l}\text { Alliance } \\
\text { purpose }\end{array}$ & $\begin{array}{l}\text { Technology } \\
\text { transfer }\end{array}$ & $\begin{array}{l}\text { Industry of } \\
\text { the alliance }\end{array}$ & $\begin{array}{l}\text { VC } \\
\text { backing of } \\
\text { partners }\end{array}$ & $\begin{array}{l}\text { Tax } \\
\text { haven }\end{array}$ & $\begin{array}{l}\text { Year of } \\
\text { the } \\
\text { alliance }\end{array}$ \\
\hline Equity & 1.000 & & & & & & & & & & & \\
\hline $\begin{array}{l}\text { Experience } \\
\text { with equity } \\
\text { alliances }\end{array}$ & $0.127 * * * *$ & 1.000 & & & & & & & & & & \\
\hline $\begin{array}{l}\text { Experience } \\
\text { with non- } \\
\text { equity } \\
\text { alliances } \\
\end{array}$ & $0.198 * * * *$ & $0.342 * * * *$ & 1.000 & & & & & & & & & \\
\hline $\begin{array}{l}\text { Industry } \\
\text { dissimilarity }\end{array}$ & $0.176 * * * *$ & $0.099 * * * *$ & $0.130 * * *$ & 1.000 & & & & & & & & \\
\hline $\begin{array}{l}\text { Cultural } \\
\text { distance }\end{array}$ & $0.450 * * * *$ & 0.329 & 0.299 & 0.458 & 1.000 & & & & & & & \\
\hline $\begin{array}{l}\text { Country } \\
\text { dissimilarity }\end{array}$ & $0.092 * * * *$ & $0.129 * * * *$ & $0.128 * *$ & 0.045 & $0.997 * * * *$ & 1.000 & & & & & & \\
\hline $\begin{array}{l}\text { Technology } \\
\text { Transfer }\end{array}$ & $0.132 * * * *$ & 0.084 & 0.149 & $0.141 * * * *$ & 0.446 & 0.025 & $0.103 * * * *$ & 1.000 & & & & \\
\hline $\begin{array}{l}\text { Industry of } \\
\text { the alliance }\end{array}$ & $0.323 * * * *$ & $0.086^{*}$ & 0.100 & $0.185 * * * *$ & $0.468 * * * *$ & $0.142 * * * *$ & $0.470 * * * *$ & $0.224 * * * *$ & 1.000 & & & \\
\hline $\begin{array}{l}\text { VC backing } \\
\text { of partners }\end{array}$ & $0.127 * * * *$ & $0.095 * * *$ & 0.085 & $0.056^{* *}$ & 0.287 & 0.011 & $0.047 * *$ & $0.064 * * *$ & $0.123 * * * *$ & 1.000 & & \\
\hline Tax haven & $0.074 * * * *$ & 0.059 & 0.142 & $0.062 * *$ & $0.931 * * * *$ & $0.233 * * * *$ & $0.035^{*}$ & 0.012 & $0.083 * * *$ & 0.000 & 1.000 & \\
\hline $\begin{array}{l}\text { Year of the } \\
\text { alliance }\end{array}$ & $0.212 * * * *$ & $0.128 * * * *$ & $0.170 * * * *$ & $0.064 * * * *$ & $0.449 * * * *$ & 0.027 & $0.057 * * * *$ & $0.084 * * * *$ & $0.113 * * * *$ & 0.021 & 0.033 & 1.000 \\
\hline
\end{tabular}

* Significant at 0.1 level; ** significant at 0.05 level; *** significant at 0.01 level; **** significant at 0.001 level $\left(\mathrm{based}^{\circ}\right.$ on LR Chi $\left.{ }^{2}\right)$. 
Table III. GEE model predicting choice for equity governance

\begin{tabular}{|c|c|c|c|c|c|c|}
\hline Variables & $\begin{array}{l}\text { Model } 1 \\
\text { Odds ratios (robust } \\
\text { standard errors) / } \\
\text { p-values }\end{array}$ & $\begin{array}{l}\text { Model } 2 \\
\text { Odds ratios (robust } \\
\text { standard errors) / } \\
\text { p-values }\end{array}$ & $\begin{array}{l}\text { Model } 3 \\
\text { Odds ratios (robust } \\
\text { standard errors) / } \\
\text { p-values }\end{array}$ & $\begin{array}{l}\text { Model } 4 \\
\text { Odds ratios (robust } \\
\text { standard errors) / } \\
\text { p-values }\end{array}$ & $\begin{array}{l}\text { Model } 5 \\
\text { Odds ratios (robust } \\
\text { standard errors) / } \\
\text { p-values }\end{array}$ & $\begin{array}{l}\text { Model } 6 \\
\text { Odds ratios (robust } \\
\text { standard errors)/ } \\
\text { p-values }\end{array}$ \\
\hline Ln Experience with equity alliances & & $1.690(0.136) / 0.000$ & $1.726(0.139) / 0.000$ & $1.955(0.214) / 0.000$ & $1.880(0.187) / 0.000$ & $1.936(0.197) / 0.000$ \\
\hline Ln Experience with non-equity alliances & & $0.579(0.033) / 0.000$ & $0.585(0.033) / 0.000$ & $0.578(0.033) / 0.000$ & $0.577(0.033) / 0.000$ & $0.583(0.033) / 0.000$ \\
\hline $\begin{array}{l}\text { Industry dissimilarity } \\
\text { - Partner in different division } \\
\text { (four digits different) } \\
\text { - Partner in different major group } \\
\text { (last four digits different) } \\
\text { - Partner in different industry group } \\
\text { (last two digits different) } \\
\text { - Partner in different industry } \\
\text { (last digit different) } \\
\text { (Base category is partner in same } \\
\text { industry; same } 4 \text { digits) } \\
\text { Industry dissimilarity * Experience with } \\
\text { equity alliances }\end{array}$ & & $\begin{array}{l}1.446(0.146) / 0.000 \\
2.141(0.287) / 0.000 \\
1.439(0.210) / 0.013 \\
1.045(0.153) / 0.763\end{array}$ & $\begin{array}{l}1.481(0.149) / 0.000 \\
2.187(0.291) / 0.000 \\
1.475(0.215) / 0.008 \\
1.058(0.154) / 0.699\end{array}$ & $\begin{array}{l}1.495(0.152) / 0.000 \\
2.182(0.293) / 0.000 \\
1.456(0.213) / 0.010 \\
1.057(0.155) / 0.707 \\
0.988(0.006) / 0.030\end{array}$ & $\begin{array}{l}1.451(0.146) / 0.000 \\
2.156(0.289) / 0.000 \\
1.445(0.211) / 0.011 \\
1.051(0.154) / 0.735\end{array}$ & $\begin{array}{l}1.486(0.150) / 0.000 \\
2.199(0.293) / 0.000 \\
1.483(0.216) / 0.007 \\
1.063(0.155) / 0.678\end{array}$ \\
\hline $\begin{array}{l}\text { Cultural distance } \\
\text { Cultural distance * Experience with } \\
\text { equity alliances }\end{array}$ & & $1.034(0.006) / 0.000$ & & $1.034(0.006) / 0.000$ & $\begin{array}{l}1.034(0.006) / 0.000 \\
0.997(0.001) / 0.036\end{array}$ & \\
\hline $\begin{array}{l}\text { Country dissimilarity } \\
\text { (Base category is the same country) } \\
\text { Country dissimilarity * Experience with } \\
\text { equity alliances }\end{array}$ & & & $1.384(0.113) / 0.000$ & & & $\begin{array}{l}1.426(0.119) / 0.000 \\
0.961(0.018) / 0.039\end{array}$ \\
\hline
\end{tabular}




\begin{tabular}{|c|c|c|c|c|c|c|}
\hline $\begin{array}{l}\text { Alliance Purpose } \\
\quad \text { - Production } \\
\quad \text { - Marketing } \\
\text { (Base category is Research \& } \\
\text { Development) }\end{array}$ & & $\begin{array}{l}4.483(0.599) / 0.000 \\
1.164(0.116) / 0.129\end{array}$ & $\begin{array}{l}4.566(0.607) / 0.000 \\
1.168(0.116) / 0.119\end{array}$ & $\begin{array}{l}4.441(0.592) / 0.000 \\
1.157(0.115) / 0.144\end{array}$ & $\begin{array}{l}4.456(0.594) / 0.000 \\
1.157(0.115) / 0.143\end{array}$ & $\begin{array}{l}4.546(0.604) / 0.000 \\
1.164(0.116) / 0.127\end{array}$ \\
\hline Technology transfer & $0.454(0.088) / 0.000$ & $0.544(0.110) / 0.003$ & $0.537(0.108) / 0.002$ & $0.545(0.110) / 0.003$ & $0.549(0.111) / 0.003$ & $0.543(0.109) / 0.002$ \\
\hline $\begin{array}{l}\text { Industry of alliance } \\
\text { - Agriculture, forestry, fishing } \\
\text { - Mining } \\
\text { - Construction } \\
\text { - Manufacturing } \\
\text { - Transportation, communications, } \\
\text { electric, gas and sanitary services } \\
\text { - Wholesale } \\
\text { - Retail } \\
\text { - Finance, insurance and real estate } \\
\text { - Public administration } \\
\text { (Base category is Services) }\end{array}$ & $\begin{array}{l}4.102(2.279) / 0.011 \\
5.815(0.812) / 0.000 \\
5.412(1.521) / 0.000 \\
2.836(0.268) / 0.000 \\
3.654(0.493) / 0.000 \\
\\
1.383(0.238) / 0.060 \\
2.064(0.490) / 0.002 \\
3.446(0.437) / 0.000 \\
2.518(1.403) / 0.098\end{array}$ & $\begin{array}{l}3.637(2.262) / 0.038 \\
5.295(0.796) / 0.000 \\
2.570(0.777) / 0.002 \\
1.157(0.147) / 0.250 \\
2.913(0.427) / 0.000 \\
\\
1.098(0.208) / 0.624 \\
1.531(0.383) / 0.088 \\
2.784(0.383) / 0.000 \\
2.463(1.535) / 0.148\end{array}$ & $\begin{array}{l}3.517(2.263) / 0.051 \\
5.225(0.783) / 0.000 \\
2.474(0.748) / 0.003 \\
1.178(0.149) / 0.196 \\
2.913(0.426) / 0.000 \\
1.143(0.217) / 0.481 \\
1.576(0.387) / 0.064 \\
2.737(0.376) / 0.000 \\
2.223(1.386) / 0.200\end{array}$ & $\begin{array}{l}3.588(2.219) / 0.039 \\
5.279(0.796) / 0.000 \\
2.581(0.777) / 0.002 \\
1.151(0.146) / 0.268 \\
2.899(0.425) / 0.000 \\
1.094(0.208) / 0.637 \\
1.551(0.393) / 0.084 \\
2.766(0.380) / 0.000 \\
2.443(1.527) / 0.153\end{array}$ & $\begin{array}{l}3.620(2.233) / 0.037 \\
5.300(0.799) / 0.000 \\
2.597(0.781) / 0.002 \\
1.152(0.146) / 0.264 \\
2.896(0.426) / 0.000 \\
\\
1.096(0.208) / 0.631 \\
1.520(0.379) / 0.094 \\
2.772(0.382) / 0.000 \\
2.476(1.541) / 0.145\end{array}$ & $\begin{array}{l}3.486(2.236) / 0.052 \\
5.216(0.783) / 0.000 \\
2.502(0.753) / 0.002 \\
1.172(0.149) / 0.211 \\
2.900(0.425) / 0.000 \\
\\
1.144(0.218) / 0.478 \\
1.562(0.384) / 0.069 \\
2.723(0.374) / 0.000 \\
2.233(1.394) / 0.198\end{array}$ \\
\hline VC backing of partners & $0.367(0.068) / 0.000$ & $0.349(0.070) / 0.000$ & $0.354(0.071) / 0.000$ & $0.350(0.071) / 0.000$ & $0.351(0.070) / 0.000$ & $0.355(0.070) / 0.000$ \\
\hline Tax haven & $1.719(0.218) / 0.000$ & $1.506(0.203) / 0.002$ & $1.507(0.207) / 0.003$ & $1.500(0.203) / 0.003$ & $1.495(0.202) / 0.003$ & $1.498(0.206) / 0.003$ \\
\hline $\begin{array}{l}\text { Year of alliance } \\
\quad-2010 \\
\quad-2011 \\
\text { (Base category is 2009) }\end{array}$ & $\begin{array}{l}2.837(0.296) / 0.000 \\
2.064(0.163) / 0.000\end{array}$ & $\begin{array}{l}2.917(0.334) / 0.000 \\
2.167(0.186) / 0.000\end{array}$ & $\begin{array}{l}2.896(0.328) / 0.000 \\
2.156(0.185) / 0.000\end{array}$ & $\begin{array}{l}2.916(0.335) / 0.000 \\
2.172(0.187) / 0.000\end{array}$ & $\begin{array}{l}2.926(0.335) / 0.000 \\
2.165(0.186) / 0.000\end{array}$ & $\begin{array}{l}2.903(0.328) / 0.000 \\
2.155(0.185) / 0.000\end{array}$ \\
\hline Constant & $0.329(0.028) / 0.000$ & $0.196(0.027) / 0.000$ & $0.198(0.028) / 0.000$ & $0.192(0.027) / 0.000$ & $0.192(0.027) / 0.000$ & $0.196(0.028) / 0.000$ \\
\hline $\begin{array}{l}\text { Model fit } \\
\mathrm{N}=3724\end{array}$ & $\begin{array}{l}\text { Wald } \mathrm{Chi}^{2}=498.94 \\
\text { Prob }<\mathrm{Chi}^{2}=0.0000\end{array}$ & $\begin{array}{l}\text { Wald } \mathrm{Chi}^{2}=725.65 \\
\text { Prob }<\mathrm{Chi}^{2}=0.0000\end{array}$ & $\begin{array}{l}\text { Wald } \mathrm{Chi}^{2}=723.84 \\
\text { Prob }<\mathrm{Chi}^{2}=0.0000\end{array}$ & $\begin{array}{l}\text { Wald } \mathrm{Chi}^{2}=723.97 \\
\text { Prob }<\mathrm{Chi}^{2}=0.0000\end{array}$ & $\begin{array}{l}\text { Wald } \mathrm{Chi}^{2}=725.12 \\
\text { Prob }<\mathrm{Chi}^{2}=0.0000\end{array}$ & $\begin{array}{l}\text { Wald } \mathrm{Chi}^{2}=721.95 \\
\text { Prob }<\mathrm{Chi}^{2}=0.0000\end{array}$ \\
\hline
\end{tabular}




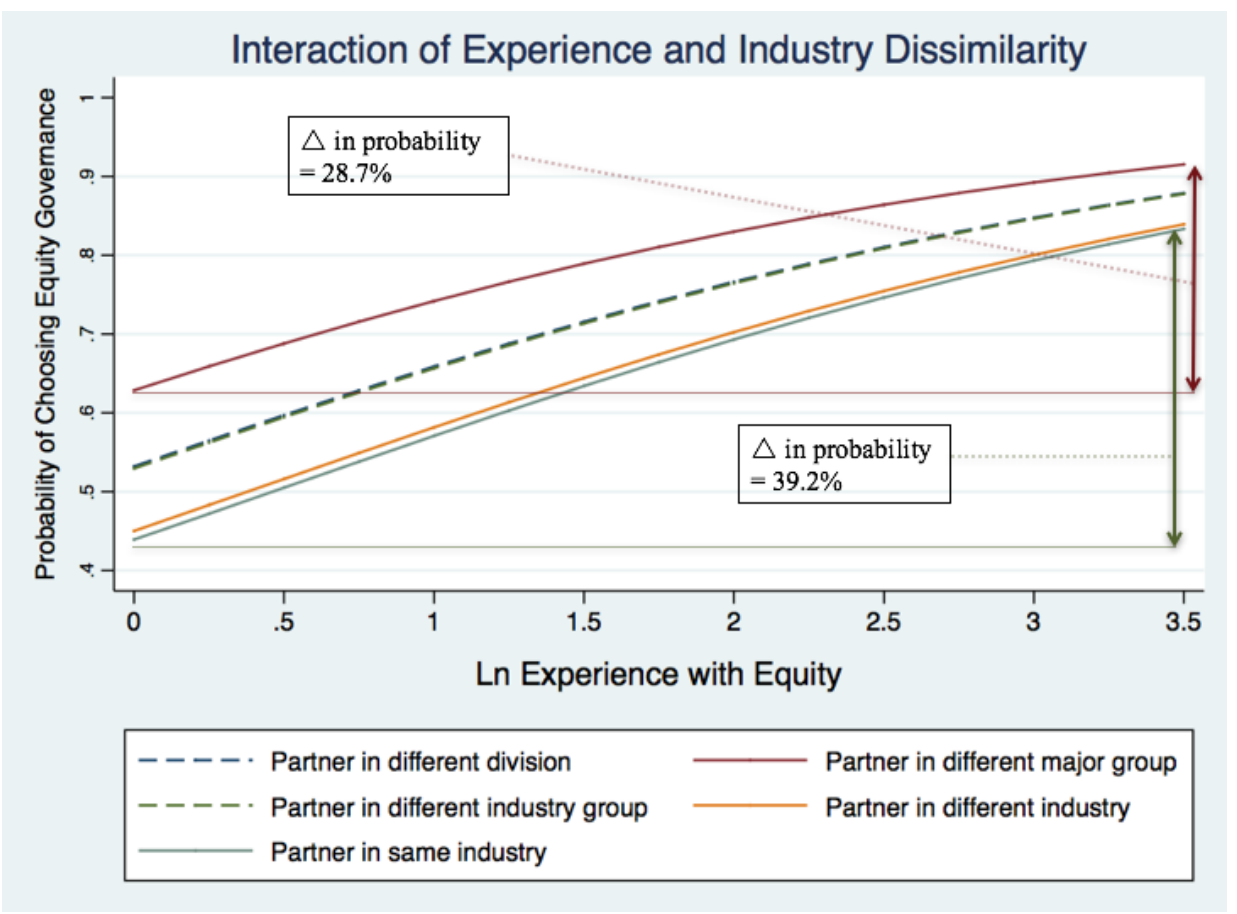

Figure 1 Interaction of experience and industry dissimilarity

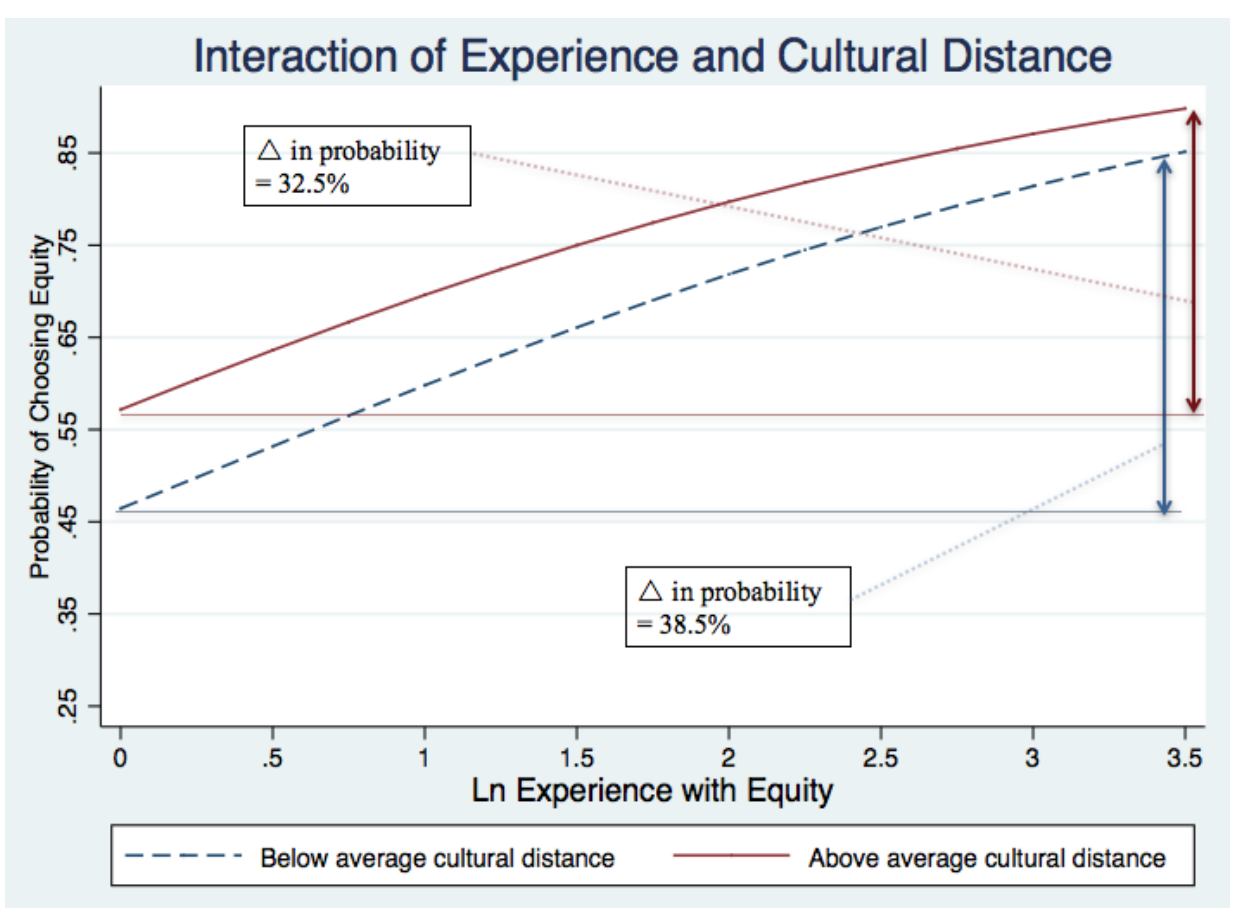

Figure 2 Interaction of experience and cultural distance 


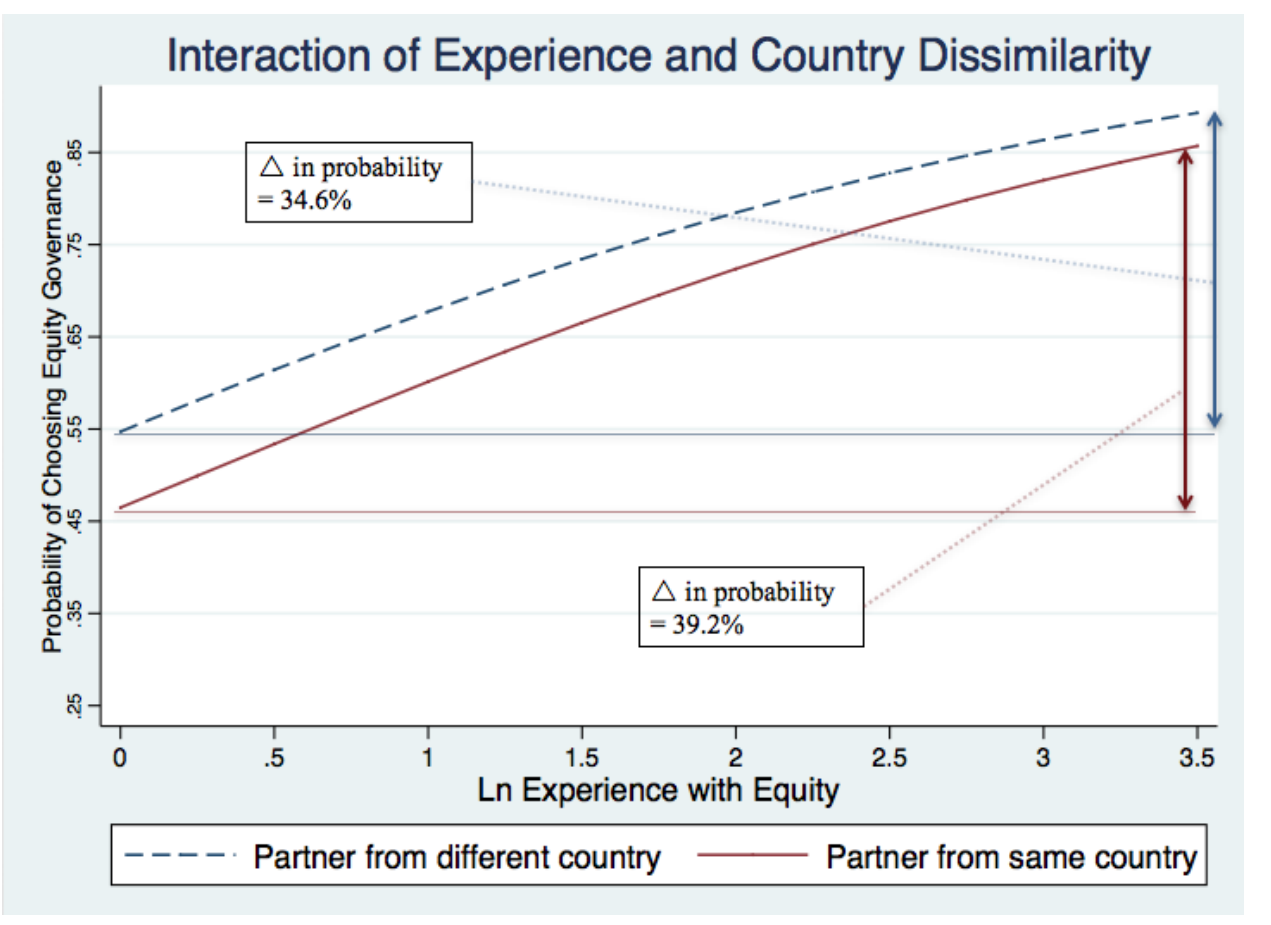

Figure 3 Interaction of experience and country dissimilarity 